\title{
Herbert, Narcissus and the Fly, or the Process of Text Creation as an Exercise in Reinterpretation ${ }^{1}$
}

\begin{abstract}
This article chronicles the travails of Zbigniew Herbert during the process of writing his short prose piece depicting the image of the mythological Narcissus. An analysis of the extant versions of the manuscript serves as a telling illustration of how multivariate the reinterpretation of this myth can be. In the laboratory of his notebook, Herbert experimented with multifarious avenues of such conceptual reimagining. Those of Herbert's texts about Narcissus which have actually been released in print are only narrowly reflective of the enormous scope of his protean creativity in the deconstruction and transformation of the canonical version of this Greek myth.
\end{abstract}

Keywords: Zbigniew Herbert, genetic criticism, archives

\section{Point of Departure: "Contrary to the Legend"}

The year 1999 saw the publication of a short work of literary prose by Zbigniew Herbert, a poet and a writer, who had predeceased the release of that prose by slightly over a year. The work, never in print before, appeared in one of the volumes of Zeszyty Literackie; it bore the title "Narcissus" and commenced with the words "contrary to the legend."

${ }^{1}$ The article was written under the aegis of the National Programme for the Development of the Humanities "Zbigniew Herbert Archives - Studies on the Documentation of the Creative Process," underwritten by a relevant grant bearing the registration number $11 \mathrm{H} 130167$ 82; the recipient of the grant was The Faculty of Polish Studies of the Jagiellonian University in Kraków; the person in charge of the programme: Dr. Mateusz Antoniuk. Originally published in Konteksty Kultury 2018, vol. 15, no. 1 (the Polish title: "Herbert, Narcyz i mucha albo proces tekstotwórczy jako praca reinterpretacji”). 
These two keynote notions of contrariness and legend highlight the modus operandi informing the aforementioned piece of writing that represents yet another recurrence of confrontational play with mythological tradition, an inclination that can be deemed emblematic of the author of String of Light. ${ }^{2}$ By the same token, the "contrary to legend" motto apparently displayed characteristics of a patently deliberate simplification or a mental shortcut. Herbert was all too cognizant of the implausibility of presuming the existence of just a single Narcissus legend, just one narrative depicting the story of this protagonist's life and death and the way they were all immortalised. Apart from the account codified by Ovid in his Metamorphoses (a beautiful youth spurns Echo's affectionate love and through this act of cruel insensitivity causes her death, in retribution for which he is smitten with ardent love for his own reflection in the water, and, as a result, pines away and perishes in the throes of unrequited love; subsequently, his death brings forth the emergence of a flower, a narcissus, sprouting forth from under the ground where Narcissus died), literature was awash with varied altered and transformed versions. According to one of them, handsome Narcissus, rather than rejecting a woman's love, spurns a man's affection. His name is Amenijas, and his further fortunes mirror those of Echo, with the remainder of the story being in full agreement with Ovid's version. Even more intriguing is yet another version: Narcissus does not reject any human affection - on the contrary, and, what is more, his love is not selfabsorbed infatuation, but affection lavished on his twin sister. After her death, he plunges into despair. He keeps gazing at his own visage with the singular purpose of seeing, albeit indirectly, the face of the one he has lost sight of and been bereaved of forever. And yet such a substitute representation cannot be tantamount to a fully-fledged instantiation, and, therefore, as the image affords no solace, Narcissus wastes away and perishes from yearning. ${ }^{3}$

Thus, upon closer inspection, the myth appears less homogeneous than the conventional wisdom would have us believe (and I must admit that my short recapitulation can by no means do justice to the full range of the nuanced palette of this myth's variants). The hero of this tale transpires to be a volatile construct: now he sees nothing but his own face as he refused to cast a glance at anyone else's, now he peers into his face because it carries the promise of descrying someone else's image. Thus, the promise of proceeding "contrary to the legend," that begins Herbert's "Narcissus," could, after all, take the form of "contrary to legends." What justifies that proposition is the fact that Herbert's reinterpretation of the Narcissus story flies in the face of the whole body of mythography inspired by Narcissus and shows no reverence to any of these

${ }^{2}$ Conf. M. Adamiec, ‘...Pomnik trochę niezupetny..." Rzecz o apokryfach i poezji Zbigniewa Herberta, Gdańsk 1996.

${ }^{3}$ See P. Grimmal, Stownik mitologii greckiej i rzymskiej, trans. M. Bronarska et al., $2^{\text {nd }}$ ed., Wrocław 1990, p. 245. 
versions. For Herbert, Narcissus is not the apotheosis of beauty. "Contrary to the legend that attributes great beauty to Narcissus, he was a commonplace boy with vulgar features, a spotty complexion, broad shoulders and lanky limbs." ${ }_{4}$ Moreover, by no means is he insensitive, nor does he disdain Echo's love.

However, brutality and stupidity require a binding agent, a third element to create a durable molecule of character. Most often that element is sentimentality. So he, too, fell in love. ${ }^{5}$

The relationship between Narcissus and Echo does come to fruition. And even when it suffers dissolution, the course of events does not lead to the literal death of any of the lovers.

There was a break-up. Narcissus did not return to his former activities. He began to ruminate.

Echo, on the other hand, entered the convent of nature. There were no other convents at that time. When groups of eccentrics, loaded down with cold chicken, sandwiches and hard-boiled eggs visit the canyons, ravines, backwoods and fields, the invisible Echo accompanies the explorers, repeating the last two words of their resounding hoots. You could say that despair drove her to become a stewardess of the natural world.

And Narcissus, as said before, mused. ${ }^{6}$

I claim membership in the segment of readership gifted with a passion for pursuing leads prompted by genetic criticism. Naturally, thus, when confronted with a finished, integral work, defined by the bookends of the beginning, the end, and what comes in between, I often spare many a thought for the literary processes and the artistic, creative meanders that have contributed to the final shape of the text I can see on the printed book pages or newspaper sheets. I am, in a way, overtaken by the curiosity inherent in the old formalistic interrogation: what are the technicalities underpinning the creation of this literary work (be it The Overcoat by Gogol, Don Quixote by Cervantes or "Narcissus" by Herbert)? Notwithstanding such a mindset, I do not aspire to give compartmentalised answers and do not set store primarily by the methodology of synchronic structural analysis, which dissects the static unity of a text into discrete elements and ascertains their functional interrelations, without, however, taking a penetrating look at the very process to which they owe their existence.

${ }^{4}$ Z. Herbert, "Narcissus," Zeszyty Literackie 1999, no. 68. [The English translation of this version comes from: Z. Herbert, The Collected Prose: 1948-1998, ed. A. Valles, trans. M. March, J. Anders, J. and B. Carpenter, A. Valles, New York 2010, p. 347-349 (translator's note)].

5 Ibid.

${ }^{6}$ Ibid. 
My desire is to proceed in terms of genetic criticism's diachronic analysis, aiming to recapture, of course within the bounds of feasibility, the process propelling the construction of the text.

\section{Narcissus in the Archives - A Rudimentary Outline}

The beginning of the in-print life of "Narcissus" was marked by its publication in Zeszyty Literackie, and the first edition's text runs over a couple of pages. But the genetic dossier of the author's work on this prose (the phrase in bold signifies the bulk of the extant documents, representing tangible traces of the text-creating process) extends over forty sheets of paper. This documentation is stored in its entirety at the Archiwum Zbigniewa Herberta (Biblioteka Narodowa w Warszawie) [the Zbigniew Herbert Archives housed at the National Library in Warsaw]. Some of the sheets are integral parts of Herbert's notebooks, ${ }^{7}$ but more often they are loose sheets. ${ }^{8}$

Could the process of the accretion of the raw material for the planned prose be pinned down to a particular timeframe? When did Herbert work on "Narcissus"? It seems impossible to give exact answers to these questions, as, with the exception of one entry, the notes are not explicitly datelined by the author. However, a thorough analysis of all available hints and leads may give grounds for a cautious hypothesis relating to chronology. We assume that the incipience of the idea for a work attempting to reinterpret the myth of Narcissus may have coincided with the second half of the 1970s. ${ }^{9}$ With fluctuating intensity, the stage of text-creation may have spanned over the 1980s, and there are grounds for supposing that such efforts continued into the first half of the 1990 s. ${ }^{10}$ We also have evidence, this time incontrovertible, that Herbert was still

See The Zbigniew Herbert Archives at the National Library in Warsaw (Archiwum Zbigniewa Herberta w Bibliotece Narodowej w Warszawie) (all documents quoted or referred to here are sourced from that resource, henceforth referred to as AZH), acc. 17955 , vol. 105, $112,120,122,136,155$.

${ }^{8}$ Loose sheets of paper are stored in files documenting the twists and turns of the creative process on The King of the Ants, an extensive prosaic project, which was to comprise the piece on Narcissus, among others; see AZH, acc. 17 856, vol. 2, 3, pts. 2, 5.

9 The title of "Narcissus" itself - situated on an otherwise blank sheet, completely unaccompanied by any of the descriptions, even a single word, later appearing in this textual work in progress - is found in Notatnik (Notebook) no. 105, roughly dated for 1978.

${ }_{10}$ In Notatnik (Notebook) 112 - which on the authority of the publication entitled $A r$ chiwum Zbigniewa Herberta. Inwentarz (The Zbigniew Herbert Archive. Inventory) (ed. H. Citko, Warszawa 2008) can be dated for 1982 and contains a short note from a newspaper article published on $13^{\text {th }}$ Feb. 1983 - we can find a fairly extensive fragment of text, undoubtedly comprising some part of "Narcissus." Evidence of preparatory work on this short prose piece can also be found in Notebooks no. 120 (the cover displays the dates of 1987 and, probably, 1991), 
working on Narcissus in July1996, two years before his death, as demonstrated by the only directly dated handwritten manuscript of this work. ${ }^{11}$ Relying on this reconstructed, approximate chronology, we may hazard an educated guess that the author of Hermes, Dog, and Star was working for almost 15 years (in an on-again, off-again fashion and with varied intensity) on his prose piece about Narcissus. Such a stretch of time seems to be significantly protracted, considering that it was a short prose piece.

From a functional point of view, the information within the compass of the dossier can be systematised in the following manner:

a) 'Blueprint' or large-scheme-of-things notes, pertaining to the characterisation of the "dramatis personae," plans for the execution of the storytelling - this information appears either in solid, structured text or in the form of bullet points for further elaboration.

b) Notebooks - more or less extensive passages of organised text, all written by hand.

c) Typescripts and computer printouts (one of the printouts was used as the galley-proof version for the first edition of "Narcissus" in Zeszyty Literackie).

Quantitatively speaking, type "c" documents are the least represented, with a more marked presence of type "a" documents; by all accounts, the largest portion of the extant documents, about $90 \%$, to be exact, is made up of type "b" material. What emerges from the documentation is that Narcissus was not preplanned in detail. It could have been so because from the very inception the author did not envision that piece of writing as anything other than a short production, with an uncomplicated plot, a limited number of characters, thus obviating the need for an elaborate composition. Nonetheless, the prose was characterised by dynamism and intensity. That dynamism of the creative process in this respect manifests itself through a series of independent attempts at constructing text, and yet in the majority of cases subsequent versions are abandoned, grinding to a halt after a couple of dozens, a dozen, or just a few sentences.

What is the reason behind this prolific and diversified multiplication of the Narcissus myth in Herbert's notes? Why does the author take pains to rewrite his short prose piece so many times, indefatigably making and breaking what is already committed to paper, only to start from scratch, with every new attempt yielding different results, and, not infrequently, 'completely different results'? What is the nature of the force of attraction this endeavour exerted

no. 122 (the cover displays the year of 1988) and no. 136 (displaying no date, but Archiwum Zbigniewa Herberta. Inwentarz gives an approximate 1986-1989 dating).

${ }^{11}$ In Notatnik (Notebook) no. 155 features an inscription featuring a redaction of the work entitled "Narcissus," datelined $17^{\text {th }}$ July 1996 (along with another date $-4^{\text {th }}$ July 1996). 
on him for all those years, which were, after all, filled with work on other creations, both in prose and verse? And how can one explicate the disproportion between the volume of the notebook-stored inspirations and the scope of the finished product? If I were to put it in a nutshell, given the paper trail evidencing his work, my answer would take the following form: Herbert's ultimate pursuit does not strive for textual perfection, for the ideal in terms of stylistic and rhetorical merit, but he keeps prospecting for the best reinterpretative concept. With each new attempt, the author strives to upend and reorient the meaning and scheme of the vintage mythological story, and yet what he harvests each time he is not fully satisfied with. It is fully warranted to say that at the core of the creative process associated with the writing of "Narcissus" lies this quintessentially "Herbertian" relish for reinterpretation and subversion of canonical, cultural narratives. However, the real mechanism responsible for the protraction and convolution of the process of creating "Narcissus" is the reinterpretation of reinterpretation, the subversion of subversion. Thus, the notes pertaining to "Narcissus" prove to be records of a process focused not only on text-creation, but primarily on myth-recreation.

Reading (or deciphering, to put it more relevantly) varied redactions, fragments of text or rough preliminary versions of this short story in manuscript, we repeatedly encounter "meta-reinterpretative" passages, and they all concern the very principle of sceptical perception of this myth as such. Almost all of them revolve around the same leading motif, the same guiding idea. And that idea is the lack of semantic transparency in the myth of Narcissus. ${ }^{12}$ The following fragment of text perfectly typifies that blurredness: ${ }^{13}$

*** The Narcissus tale is narratively weak, and its moralising thrust is unclear his person

Whatever concerns is woven from fleeting shadows - you think Charm, handsomeness, grace and beauty - what do all these amount to, barely insipid words which, tossed into the water, will leave no ripples

${ }^{12}$ It would have been only on one occasion that Herbert jotted down a comment featuring content pointing out to the contrary: "In the story of narcissus there is an important admonishment" [with an overwritten inscription: we cannot help spotting an important admonishment] (AZH, acc. 17 856, vol. 2, p. 56). However, that declaration of hermeneutical transparency of the myth, metaphorically speaking, is suspended in the vacuum of the remaining blank space of the sheet of paper. The inscription breaks off abruptly, and the introduction is not followed up upon: We will not find out what kind of "admonishment" we can easily spot in the mythological story and what significance it carries.

${ }_{13}$ All notebook inscriptions are reproduced in this article by means of transliteration, aiming for faithful rendition of the original layout of the entries. For this purpose, the following system of notation has been adopted: (...) - an illegible word, chasseders - crossouts in the original, [?] - signifies uncertainty as to the hypothetical variant decided upon (applied to the word preceding the question). 
on the surface, but is it really so or is it the case that we ourselves, we murderers of mysteries do not want to see beyond the fabric of delusion throbbing with pain

- the burdensome Essence of Things, the essence where dark pain keeps pulsating (AZH, acc. 17 856, vol. 2, p. 48)

Or in the following paragraph excerpted from another textual attempt:

\section{NARCISSUS}

If there is anything interesting in this story of Narcissus, it would be this (hard to say if it is by design or chance) clumsiness and incongruity of the story's content as if it were concocted by a frightened child sweating all over and stammering, a child right in front of us panting with purple-suffused cheeks because of agitation and trying to cough out that in the morning while picking blueberries in the forest it stumbled upon a tiny mound overgrown with blades of grass and in it were pieces of stone as if fragments of a smashed bas-relief sculpture lying under a heavy layer of earth overgrown with green and luxuriant grass, completely helter-skelter, baffling and lying there for long, mysterious pieces of something big and the child (....) forest is struggling to catch our fancy and galvanise us into action, repeatedly swearing that it is telling but sheer truth.

(AZH, acc. 17856 , vol. 2, p. 64)

And one more example, one more remark tossed in as an aside by this writercum-reinterpreter:

The myth of Narcissus, unclear, fragile, unsettling, has been classified by researchers as a vegetative myth as if

they tried to smother the plea coming from the precipice, the

cradle of a cruel fate

a tragedy, (...) (...) (even) the source of fate.

(AZH, acc. 17 856, vol. 2, p. 45)

The mythological message is consistently framed here as a narrative which is unsettling on account of its suspiciously seamless obviousness. In this respect, the inherited conventional cultural narrative is something we have to break through in order to attempt to tease out whatever is authentic; but even though there is something real in there, it does not even peek through the inconsistencies and chinks in the armour of the discourse dominating the mythography. Still, this quiddity does indwell there.

Metaphorically speaking, the process of writing and rewriting "Narcissus" (the short prose piece), endlessly recreating Narcissus (a hero, whom the reams of new notes in the notebooks invest with multiple personalities) amounts to 
a relentless struggle to get through and reach out for that "something," for "that reality." Or, if you will, this process represents a desire to stage a rhetorical spectacle, an ambition to improvise or playact a hermeneutic process, purportedly seeking to elucidate the quintessence of the myth. The hindrance, however, is that despite the abundance of experimentation, Herbert cannot achieve certitude that the meaning hitherto hidden from view has been reached; alternatively, he still yearns for a deeper conviction that he has been sufficiently cogent in "setting up" the hermeneutic process.

And it is this very creative tension, and to be specific, its paper trail left behind in the notebooks, that lies at the heart of this outline.

\section{Narcissistic Variations}

A detailed examination of the content of the archival material allows for the isolation of at least three variants of the reinterpreted character of Narcissus that are experimented with in Herbert's notebook laboratory; and yet those constituting the readership of the legacy of the author of The King of the Ants are not familiar with any of those variations. These three conceptions, each of them appearing in at least three attempted executions of the idea, can be subsumed under the following three encapsulations: Narcissus as a philosopher thirsting for self-knowledge, Narcissus tragically rebelling against his destiny, and Narcissus as a philosopher of self-destruction. Now, I will try to explain the meaning of these labels respectively, and how they transmit themselves into text in practice.

a) Narcissus as a philosopher thirsting for self-knowledge

Let us look at the following transliteration:

Narcissus II

The most suitable for this purpose are secluded places

It is common knowledge that the most suitable place for this purpose are secluded ones. Our hero

then

ensconced himself in a dense forest. The whole of the life he had lived so far seemed bereft of meaning. He sensed a fuzzy desire for self-knowledge beginning to burn in him

The most suitable for this purpose are, as everyone knows, depopulated backwoods. Our hero, then, ensconced himself in a dense forest. The whole of the life he had lived so far seemed bereft of meaning. And what flared up in him, smouldered, desire

was an unclear yet strong appetite for knowledge. (...) 
Over innumerable centuries preceding the advent of philosophers with their salutary [?] baggage of abstractions, we were tormented [?] by the same grand conundrums relating to God, the world, subject, object, except that they assumed the guises of images, (...) myths, nightmares. We have to do Narcissus justice long before Socrates he had risen to the challenge of grappling, albeit naively but with gusto, with the Socratean precept of knowing oneself.

(AZH, acc. 17856 , vol. 2, p. 51)

Thus, Narcissus turns out to be a pre-Socratic. Or, rephrasing that idea, he is a Socrates avant la lettre, a foreshadowing of the great Athenian and the protagonist of Cave of Philosophers, which, by and of itself, was largely concerned with the issue of introspection and self-knowledge. What was the outcome of Narcissus's rumination? What certainties regarding himself as a thinking subject was he, that first philosopher of subjectivity, able to tease out in his cogitation? As shown in the transliteration above, the text breaks off abruptly, more or less in mid-page. And below, where one would expect a continuation, there is a blank space. Except that near the bottom margin on the same page, at a significant distance from the passage we have been analysing, appear the following words:

on

suddenly

He started pondering who he really was. Who could have supposed that such an abyss would open up before such a simpleton?

Thus, the trajectory of this projection of Narcissus was to guide the hero to the experience of the horror of self-knowledge. But what about the chasm what reality did it stand for? Of course, we may confidently aver that he was a chasm for himself, that he was engulfed by his own subjectivity. True, but still we do not know what he stared at in that chasm. Nor do we have any knowledge if Herbert himself had any idea in this respect. It seems admissible and dismissible in equal measure that Herbert, the reinterpreter, did not envision what the reinterpreted hero was to discover about himself. Henceforth, the whiteness of the blank space may represent a lacuna in the reinterpretative process of the myth, and it may also be a testament to the fiasco of the travails of the "subversive" imagination ultimately falling short of furnishing the polemic, countercultural reading with closure.

The conception of Narcissus as a philosopher preoccupied with gaining selfknowledge recurs in the notes on a couple of occasions, each time tinged with different overtones. From the standpoint of intertextuality, two margin notes appearing on different sheets are particularly intriguing: they include phrases such as "egotyczna religia" ("egotistic religion") and "o [?] swój [?] poswoje do swego" ("for [?] one's own [?] for one's own to one's own”) (AZH, acc. 17 856, vol. 2, p. 65). The latter formulation seems to ring a bell, as "Swój do swego po swoje!" (For 
one's own to one's own!) is a catchphrase frequently repeated in Gombrowicz's Cosmos. It even achieves iconic status there, as it becomes emblematic of the philosophy of life of one of the characters, Leon Wojtys, who restricts, on principle, his contact with the outside world and derives satisfaction from keeping himself to himself (with respect to his physicality, memory, imagination, private language, etc.). ${ }^{14}$ Shall we chalk it up to a coincidence? Or maybe, as I do, we should reckon with the possibility that Herbert's work on the reinterpretation of the myth puts him in mind of Gombrowicz's novel. Herbert had once been an avid reader of Gombrowicz, even though over the years his enthusiasm started to wane, finally giving way to detachment, distrust, and alienation. ${ }^{15}$

b) Narcissus tragically rebellious against his destiny

In the labyrinth of the notebook, we stumble upon another Narcissus:

In

Narcissus The Late-Hellenic Almanach de Gotha he figures as the son of a naiad and the god of a tiny rivulet the god of a tiny rivulet and a naiad

No doubt, Narcissus's beauty was an insidious or mindless gift of gods; he inauspicious

himself never craved for it, as if foreknowing that it would become his sinister doom. [There is lack of information with regard to the childhood or early

boyhood of Narcissus, although we know that from his early youth he rebelled against.

but we do know for sure only that he was

[..] we also know that he was a lessee of a mill so he was a miller, a small enterpriser, which in the social hierarchy guaranteed a station neither too elevated, nor too lowly.

14 "Himself to his own for his own" is also a nationalistic battle cry used in the interbellum period, exhorting Poles to boycott Jewish commerce and trade, embracing Polish retail enterprises. However, I leave this issue aside, focusing in my interpretation on a possible allusion to Gombrowicz.

15 See the letter to Halina Misiołkowa from $1^{\text {st }}$ June 1956: "I have been reading Gombrowicz's Dziennik in 'Kultura' (Parisian). I have not experienced such profound agitation for a long time. He could easily be the greatest Polish contemporary writer: shrewd and sagacious, shocking, provoking. And he displays such insight in analysing other people's ideas" (Z. Herbert, Listy do Muzy, Gdynia 2000, p. 132). But ten years later, this time another recipient of a letter from Herbert would hear a different tune - one cautioning against the author of Dziennik: "I am deeply concerned about your spiritual affinity with Gombrowicz (...). Beware, he may be an artist, but he depraves people" (Z. Herbert, C. Miłosz, Korespondencja, Warszawa 2006, p. 73, a letter from $11^{\text {th }}$ May 1967). That remark from the letter to Miłosz is laced with humour indeed, but when confronted with the previous epistolary passage, it seems to give legitimate grounds for a suspicion of some growing disaffection. 
As he was a middle-of-the-road human being, both in terms of his political views and in other respects, beauty he personified as a nuisance, as a role imposed on him, he did not want to playact beyond did not want to play

in other fields

As he was a middle-of-the-road person in terms of his political views and in other respects,

his own

he perceived the beauty he was doomed to as something incongruent with his nature, as if it were a part in a play whose meaning was inconceivable to him. He rebelled from his early childhood against all those who were adamant to and it is that very rebellion that imparts a truly tragic streak to his character, contrary to what others thought when they thrust this cha send

Narcissus to botany, into the realm of fuzzy vegetation myths.

(AZH, acc. 17856 , vol. 2, p. 43)

This incarnation of Herbert's Narcissus is not so much fixated on "selfexploration" as he is at variance with himself, trying to negate a particular profile of his identity. Herbert subjects this myth to dynamic galvanisation; the traditional, static character, defined by an immutable disposition, is being furnished with internal struggle, or even innermost rupture.

What was Herbert's plan for resolving the argument between Narcissus and gods (who endowed him with physical beauty), the surrounding world (that immediately spotted and focused on nothing but that beauty) and, last but definitely not least, his own strife with the principle of his own individuation? The question has to remain unanswered because, not unlike in the case of the Narcissus being swallowed by the chasm of self-knowledge, here as well we are left with nothing, as the text is stopped, jettisoned, and never finalised. In light of the unfinished text, we can only conjecture that the myth of Narcissus here was destined for "transcoding" along the lines of the myth of Oedipus. Narcissus is endowed here with beauty that by the same token can be an "ominous destiny"; hence, any desire to renounce it would be tantamount to trying to escape one's fate or from whatever is preordained and must happen. But what might have been the blueprint for the trajectory of Narcissus's further life? What particular vicissitudes might have been triggered by the mutinous behaviour of the character picking up the gauntlet thrown down by the ineluctable? 
c) Narcissus, a philosopher of self-destruction

The following lines, retrieved from Herbert's notebook, are the most instrumental in pinpointing the last of the three delineated reinterpretative concepts:

We cannot exclude that Narcissus, apparently

unwittingly, originated a quite popular nowadays

movement which for want of a better word we may call

de-grationalism, or more convolutedly, hence better,

integral de-grationalism

The fundamental tenet of this conception is

the intuition that man was created over and above

the scope of his capacities (most of us can to a greater or

lesser extent feel it). And if it is so, or

seems to be so - the only reasonable course of action

is not ascending, exerting oneself, perfecting oneself

but deliberately declining, degrading, descending

down $[\ldots \ldots \ldots . . .$.$] towards$

ever simpler forms of life. Existence is packing up

its bundle and absconds to the essence. That seems

to be the story emanating from the notes found on Narcissus

maybe the outline of a poem

It feels so good

So good

the trees go back to their homes

And the clouds to their homes (dens)

the sky disappears in the skies

Me and only me

Myself self-substantial immaculate

holy

Myself

peace. More and more light

*/ Clouds to their (...)
What bliss. The sky disappears in the skies

Clouds to the clouds trees to the forest.

Me and only me indivisible

Me self-substantial, immaculate holy

Myself

Peace. More and more light.

(AZH, acc. 17 856, vol. 2, p. 66)

One cannot help but notice here the strongest affinity with a previously outlined version of Narcissus, namely the one rebelling against his own beauty. But this iteration of Narcissus is patently more radical: he renounces something more than his facial beauty, as he abjures the human form of existence. And the plan is accomplished:

- Finally the inevitable materialised. In popular parlance, this expression is as short as the noise of a snapping branch. The descriptive definition offered by biology 
tries to assuage that painful feeling by means of stoical objectivity and says that it is a state of our organism (thus a state nevertheless)

manifesting itself in the cessation of all life processes, leading to the annihilation of an individual as a living system. Yes, the latter is much easier to bear.

Those who discovered Narcissus's dead body by the spring were amazed to see that he was well-preserved, desiccated like a leaf and almost two-dimensional.

Admittedly, this is the only case known to the world of science where we discover regressive development consisting in simplification, contraction of certain organs and diminution of function. In Narcissus's case, one could observe devolution of the organs of movement, and some other organs excluding the eye, and decline in any form of active nourishment. Such regressive development is encountered, among others, in internal parasites, which compensate for this freak of nature with progressive [?] development of the reproductive system, which was not [?] the case [?] in Narcissus' s instance.

(AZH, acc. 17 856, vol. 2, p. 66)

This Herbert-begotten Narcissus does not plunge into the chasm of selfknowledge, steering clear of any embroilment in the Oedipal altercation with his destiny (which is embodied in the scourge of his beauty), only to effectively succumb to self-regression. He fixates on himself, but in a paradoxical way which obscures and completely obliterates his "self." This Narcissus performs an act of self-denudation and self-desolation. In other textual attempts, Herbert found a relevant metaphor for the description of such behaviour in his reinterpreted character: "Narcissus is a cannibal sui generis, one that cannibalises himself" (AZH, acc. 17 856, vol. 2, p. 56).

The metaphor of "a laboratory," which has recently come to the fore and gained recognition in the field of Polish literary studies, ${ }^{16}$ aptly lends itself to the description of Herbert's writing process - the very same process my article deals with. Every given set of notes bears some conceptual resemblance to a laboratory vessel - in each of them the writer-experimenter tests varied proportions and compositions of ingredients. And usually such "work" is not brought to fruition, as, rather than put a premium on the final result, the finished product, the author is more interested in executing a simulation and investigates what properties are displayed by a piece of text configured according to a specific recipe. Once the outcome is clear, the experimenter aborts the test, proceeds to another test tube, looking for new solutions. Let us reiterate those hitherto encountered versions of Narcissus: a Narcissus trying to fathom the mysteries of

16 See R. Nycz, "Towards Innovative Humanities: the Text as a Laboratory. Traditions, Hypotheses, Ideas," trans. A. Warso, Teksty Drugie 2015, no. 1, Special Issue - English Edition. 
his own unexpectedly complicated "chasmic" personality (version a); a Narcissus renouncing the flamboyance of his beauty in the name of being "a middleof-the-road human being" (version b); a Narcissus embracing self-destruction (version c); and finally a Narcissus devoid of any philosophical temperament, bereft of reflection, and hardly beautiful (the version published in Zeszyty Literackie). Each of them deviates from the mythologically canonical Narcissus, each executes a subversive attempt on the canon, but at the same time each differs from the other Narcissuses from the "fringes of the myth." Additionally, all Herbert's incarnations are mutually nonidentical, nonequivalent and noninterchangeable. If we allow ourselves to wax metaphoric once again, the creation of the prose piece entitled "Narcissus" smacks of setting up a chamber of mirrors, where we can experience the spectacle of similarities and differences, replications and distortions, reflections and transformations.

But it is not only the character of Narcissus that is inflected by such notebook variations. Emerging from the notes is a picture of his less dynamic and less emotionally stable mythological companion. In the version of "Narcissus" released in Zeszyty Literackie, Echo seems to be autistically withdrawn and living in a world of her own:

How to describe Echo's handicap? Some said she was mute, but that term is not accurate. For Echo literally and clearly repeated the last two words that ended any sentence directed toward her. However, she never spoke on her own initiative. It accorded entirely with her nature—indolent, phlegmatic, passive.

The majority of Herbert's textual experiments feature a reasonably consistent female character, with the exception of the versions of the myth that are discarded so prematurely, or are so fragmentary in nature, that the character of the nymph does not figure in them yet. That said, a thorough analysis of the notes yields detection of at least one counter-version, deviating from the "genuine myth" to the same extent as the majority of Herbert's distortions of the myth do.

she made up a strange [?] plan to stimulate an intellectual passion in Narcissus

Echo did some bedtime reading for him and chose a fairly easy work,

Kant's Allgemeine Natur geschichte und

Theorie des Himmels

Nothing, no experience, even as painful as separation from Echo could mar the ideal state of his face.

work

$\mathrm{N}$. as if collective wish could erea[?] wonders N. kept growing more beautiful ever $\mathrm{m}$

was gaining in ravishing beauty courtesy of the eyes

looking admiringly at him

(AZH, acc. 17 856, vol. 2, p. 40) 
Thus, Echo's image has parted associative company with her doppelganger, Gombrowicz's Iwona (for good measure, as we have alluded to Leon from Cosmos before), who fascinates by means of her eerie, introverted, inscrutable mode of existence. Echo has morphed into a savant, a learned blue-stocking courtesan, who embarks on the mission of fostering a metaphysical streak in Narcissus's temperament. That seems to be a forlorn hope, as in this version of the myth Narcissus is "a doltish dandy," as Witkacy would have put it, a person debased to the point of animalisation, and too obtuse to savour the mystery of life.

\section{Digression and Retrospection: Yet Another Narcissus Created by Herbert}

Let us put aside the notebook-based experiments of The King of the Ants for a while and reach back to older, and therefore deeper lamina of Zbigniew Herbert's archives. The truth is that the germination of the character of Narcissus in Herbert's imagination was not jumpstarted in the period of the author's engagement with mythology-based prose pieces in the 1980s and 90s. In actual fact, the image of Narcissus had been employed by Herbert a couple of decades before. In 1953, the poet was working on a poem entitled "The Vistula," ${ }^{17}$ which never reached the stage of completion. It was envisioned as a poem where the eponymous Vistula River was allegorised as a reflection of Polish fortunes and history. The poem spoke of, or rather would have spoken of, the recurrence of calamitous events in the collective biography of each subsequent Polish generation. The Vistula was referred to as "a barren Nile," imparting the land with the lethal fecundity of recurrent wars "from generation to generation." And in such a semantic milieu, the resonances engendered by the invocation of the trope of Narcissus were very interesting:

river

I am leaning over a murky

and I know the face [?] awaits in vain (...)

to get its reflection in the water

tod by a nacisus ound

over which everywhere a song rings out and Narcissus utters curses

which is cursed by a song and a narcissus

(AZH, acc. 17 955, vol. 46, p. 7)

${ }_{17}$ An extensive account of my exploratory work on this material can be found in my book entitled Stowo raz obudzone. Poezja Czestawa Mitosza. Próby czytania, Kraków 2015, pp. 177-181. 
The changes to the closing, fourth line afford profoundly intriguing food for thought. As seen in the transliteration, the verse is subjected to a threefold alteration, and appears in three different redactions. The meaning of the first redaction, all struck through, could admittedly be recaptured by means of the following paraphrase: the Vistula River is such that no Narcissus would ever fancy looking at his reflection in it, for, as we know from the neighbouring verses and stanzas, its murky, dark, and gloomy waters cannot lend themselves as a mirror to his self-obsessed beauty. We can hear echoes of this message in the third redaction, which came last, chronologically speaking: "which is cursed by a song and a narcissus." But sandwiched in between these two redactions is the second version, whose semantics stand out significantly from the other two. "Over which everywhere a song rings out and Narcissus"... Resonating stridently in these words is the suggestion that the banks of the Vistula are inhabited by narcissuses, that the traumatic, miserable, and bruised "Polishness" is narcissistic in character and consists in pathological exultation in fateordained victimhood. We could couch this interpretation otherwise: whereas in the first redaction, Narcissus could not live by the Vistula, as the forbidding "circumstances of life" there do not agree with him, in the middle redaction, it is the populations living near the river that prove peculiarly narcissistic, forever contemplating their own image reflected in the waters of the depressing river. Thus, the nightmarish self-images they see simultaneously engender selfexhilaration and self-torment.

In the poem "The Vistula," dating back to the 1950s, the narcissistic myth was harnessed to metaphorically frame the part of Polish discourse that pertained to the nation's fortunes past, present, and future. But when in the 1980s and 90s Herbert was sketching out the blueprint for his short story about Narcissus, the application of the same myth did not encroach in the slightest on the territory of the "Polish question." Therefore, without a shadow of a doubt, we are dealing here with two distinct, substantively different, and by all means unrelated, literary applications of this myth. And yet, we cannot fail to acknowledge in them the shared presence of the following uncanny similitude: in both cases, Herbert, working on a text relating to the narcissistic myth, seems to be fighting a losing battle with respect to finalising his vision. The poem, "The Vistula," never reached its final, definitive print-worthy version, hence remaining unreleased. The only surviving fragment did not amount to more than the final four-verse chunk, which later was incorporated into the poem entitled "Prologue" as its final lines. Likewise, the short story entitled "Narcissus" had its fair share of growing pains, kept unravelling on account of versions aborted in midtext or discarded at the near-finished point, and finally Herbert was not able to submit any manuscript for printing. Thus, by dint of some weird coincidence, the arrival of Narcissus in the poet's projects invariably and inexorably spelt complete disaster or significantly hindered the process of writing. 


\section{Did Herbert Kill the Fly and Narcissus?}

In the dossier of short prose, we stumble upon this inscription:

I have been haunted by the myth of Narcissus for many years and immediately, I will add to take the bull by the horns provo But it haunts me to no avail king provoking unproductively, provoking swelling irritation the kind of irritation - as when a huge, black fly flew in the early afternoon

into the room when on an August one I stretched out on the old-fashioned chaise longue, a book in hand and pleasant full of blissful hope in my heart to have a nap and then when the room was invaded by the aforementioned dreadful fly and I immediately thought of Narcissus (the fly and Narcissus merged in my mind into an inseparable pair

on that and exactly on 4th July 199 . I decided to put an end memora to this, scientifically speaking, - perseverant thought ble

17 th June and with one energetic man's swat kill in one fell swoop kill both the fly and Narcissus.

(AZH, acc. 17 955, vol. 155, p. 10)

In Notebook no. 155, as a continuation of the fragment featured above, we can find some other observations:

a) that he was never capable of discerning any deeper meaning in this mythological tale ("As far as I am concerned, Narcissus has always come across as someone pathetically boring"),

b) that the only artistic mind in the history of literature that was capable of profiling Narcissus in an engaging way was Ovid ("but then again he could do everything"),

c) that Narcissus has become the subject of psychoanalytical dissection, yet, by the same token, this kind of human exploratory activity raises significant misgivings as to its legitimacy and usefulness ("it would be worth our while to develop effective immunisation against psychoanalysis”).

Underneath the last sentence of this version, Herbert supplied the date of $17^{\text {th }}$ July 1996. 
At the time the entries taken down on that July day, or perhaps more appropriately, in those July days, were being logged in Notebook 155, the vast majority of the hypothetical approaches to the character of Narcissus I have undertaken to discuss here had already been put down on paper. It is not even beyond the pale of probability to posit a radical proposition that not only a majority but all of them had been committed to paper, thus the $17^{\text {th }}$ July perspective on the Narcissus subject was the last such reflection. Certainly, the "fly" inscription transliterated above ought to be treated as a commentary on the long period of "narcissistic variations."

Indeed, the myth of Narcissus had disquietingly "haunted" Herbert's imagination, and we have discussed many concrete testaments to that unrest. And indeed, the unrest had lasted "for many years." The prose piece entitled "Narcissus" was on Herbert's artistic agenda from the end of the 1970s, and if we take into consideration the unfinished poem "The Vistula" from the 1950s and the way it treats the motif of a Polish Narcissus, we will get some conception of this long-lasting thematic obsession. And finally, this persistent preoccupation indeed followed a pattern that was "to no avail, unproductive." Patently, almost all attempts at spinning the Narcissus story snapped off and came to a standstill, and even though there were some accomplishments in the form of the few stories that finally reached closure, the success was nevertheless qualified, as those typescripts or printouts were not submitted to any publisher with a view to publication.

The passage quoted above exhibits a private, authorial metaphor, casting some light on the dynamics shaping the course of the writing process, and it is worth stressing that the metaphor exudes violence. However, it is also worth mentioning that the metaphor's semantics are not free from ambiguity. Can we unequivocally determine what this figurative swatting of a pesky fly stands for? Certainly, it may mark the act of liberating oneself from the obsessive exploration of the myth. But how? Does the liberation refer to the overdue production of that single, fully compelling narrative piece, enshrining the ultimate, optimal reinterpretation of the myth? Or maybe, the way forward is the definitive cessation of any attempts at reinterpretation, as well as becoming fully resigned to the fact that this much-deliberated and long-incubating piece has not been written yet, and may very well remain unwritten forever. There is no possibility of answering such questions unequivocally, as we are in the dark about intentio auctoris. Nor can we judge on the strength of a reliable argument if Herbert really "killed the fly," releasing himself from the obsessive reinterpretation of this myth. In reality, despite the declaration made in Notebook 155, he may have been in pursuit of "the fly" until the end of his active writing days, which should translate along the lines of "until the end of his living days, he did not let go of" Narcissus. All these questions lead further into the dark environs of the cul-de-sac alleyways of the writer's mystery, impenetrable to light. 


\section{Reaching the Destination: A Genetic Edition of "Narcissus"}

The decision made by the first editors regarding the choice of Narcissus material for publication obviously had its clear rationale and justification. They proposed to use Herbert's "Narcissus variations" and isolate one integral text, albeit not necessarily the latest version chronologically, and not necessarily the one that would have secured the author's endorsement, as that was unascertainable. Nevertheless, the selective process certainly favoured the most finished version. And I am far from raising any objections thereto. All I wish to do is to broach the issue of the confection of an edition different in character, in purpose, though admittedly catering for a narrower readership. To cut a long story short, I am making a case for a genetic edition.

To get a foretaste of such an edition, it suffices to turn to the execution strategy adopted by Ryszard Krynicki, who himself offered a redaction of "Narcissus" in connection with the 2001 meticulous editorial reconstruction of The King of the Ants, as the former work constitutes part and parcel of the latter one. Once the researcher established intimate familiarity with the archival material, he chose to privilege for the inclusion in The King of Ants the exact version of "Narcissus" published in Zeszyty Literackie two years later. It included a twist, though, as "the central core" of his book was supplemented with an appendix, bearing the subtitle "Other versions of some of the works." That was where he included a hitherto unpublished version of "Narcissus." That version was significantly different from the "canonical" one in that it had its lexical and phraseological idiom, a different length and a different take on the myth as such. When it came to those of his criteria that coincided with those used for the selection of the "canonical" version, he also favoured material that was reasonably finished and was in the form of computer printouts.

A genetic edition of Narcissus that I have in mind would be a more radical solution. It would release into the public domain all the extant material having some association with Herbert's work on the myth. The publication would feature colourful reproductions and transliterations of all existing notes, the incipient, unfinished or fragmentary texts included. The edition would undoubtedly be a collection of variants, and not only the variants of one privileged version, but variants reinterpreting one myth and taking the form of many, most frequently unfinished versions, subsumed under one collective title of "Narcissus."

The edition I am encouraging here would furnish the reader with the ultimate opportunity for interacting with the "notebook polyphony," or, if you like, the full spectrum of "narcissistic variations" by Zbigniew Herbert. And that is exactly what I have set out to outline in this article. It must be added that, of necessity, this account is marred by incompleteness. I have not included by means of transliteration all existing attempts - or "half-attempts," or "quarter-attempts" - at constructing a literary work reinterpreting the canonical, 
mythological narrative; nor have I done justice to all the shades and moments of Herbert's subversion. My genetic-criticism discourse has been doomed to selectivity. A genetic edition of "Narcissus," or I would rather say of all series of unfinished works entitled "Narcissus" and written by Herbert in the 1980s and 90s, would empower readers to make their own observations, which, as a matter of course, could differ from those presented in this overview. Such an individual perspective could lead to a different distribution of emphasis, possibly different from my centres of gravity. Thus, the long and the short of it is that the reader could enjoy a direct experience of the excitement of interacting with the pre-text, rather than having to be beholden to a perspective resulting from the narrative propounded by a mediating researcher.

Translated by Przemystaw Michalski

\section{Bibliography}

Adamiec M., '...Pomnik trochę niezupetny...' Rzecz o apokryfach i poezji Zbigniewa Herberta, Gdańsk 1996.

Antoniuk M., Stowo raz obudzone. Poezja Czestawa Mitosza. Próby czytania, Kraków 2015.

Archiwum Zbigniewa Herberta. Inwentarz, ed. H. Citko, Warszawa 2008.

Grimmal P., Stownik mitologii greckiej i rzymskiej, trans. M. Bronarska et al., ed. 2, Wrocław 1990.

Herbert Z., The Collected Prose: 1948-1998, ed. A. Valles, trans. M. March, J. Anders, J. and B. Carpenter, A. Valles, New York 2010.

Herbert Z., Listy do Muzy, Gdynia 2000.

Herbert Z., "Narcyz," Zeszyty Literackie 1999, no. 68.

Herbert Z., Miłosz C., Korespondencja, Warszawa 2006.

Nycz R., "Towards Innovative Humanities: the Text as a Laboratory. Traditions, Hypotheses, Ideas," trans. A. Warso, Teksty Drugie 2015, no. 1, Special Issue English Edition. 